\title{
DIRETRIZES CURRICULARES DA PEDAGOGIA: IMPRECISÕES TEÓRICAS E CONCEPÇÃO ESTREITA DA FORMAÇÃO PROFISSIONAL DE EDUCADORES
}

\author{
José CARlos LibÂNeO
}

\begin{abstract}
RESUMO: A Resolução do CNE que institui as Diretrizes Curriculares Nacionais para os cursos de graduação em pedagogia reacende o debate em torno da natureza do conhecimento pedagógico, do curso de pedagogia, dos cursos de licenciatura para a formação de professores e do exercício profissional de professores e especialistas em educação. Este artigo traz uma exposição crítica ao conteúdo do documento, indicando que mantém antigas imprecisões conceituais com relação ao campo pedagógico que não contribuem para a superação de problemas acumulados na legislação sobre o assunto e, por isso, pouco avança na promoção da melhoria qualitativa das escolas de educação básica do país. As insuficiências dos pontos de vista teórico e prescritivo da Resolução demandam um outro entendimento do conceito de pedagogia e, em conseqüência, outra opção curricular para a formação profissional de educadores, sejam eles professores ou especialistas em educação.
\end{abstract}

Palavras-chave: Diretrizes curriculares para o curso de pedagogia. Políticas de formação dos profissionais da educação. Conhecimento pedagógico. Formação pedagógica. Formação docente.

CURRICULUM GUIDELINES OF PEDAGOGY:

THEORETICAL IMPRECISIONS AND NARROW CONCEPTION OF THE PROFESSIONAL TRAINING OF EDUCATORS

ABSTRACT: The Resolution of the CNE (Brazilian Board of Education) instituting National Curriculum Guidelines for pedagogy undergraduate courses revives the debate around the nature of peda-

* Professor da Universidade Católica de Goiás. E-mail: libaneojc@uol.com.br.

$\mathrm{O}$ autor agradece a leitura e as sugestóes feitas ao texto pelas colegas Selma Garrido Pimenta e Maria Amélia Santoro Franco e, muito especialmente, o privilégio de poder compartilhar dos mesmos ideais e práticas, pela grandeza e dignidade da escola, dos professores e de seus alunos.

Educ. Soc., Campinas, vol. 27, n. 96 - Especial, p. 843-876, out. 2006

Disponível em <http://www.cedes.unicamp.br> 
Diretrizes curriculares da pedagogia: imprecisōes teóricas...

gogical knowledge, of pedagogy courses, of licenciatura courses to train teachers and of the professional exercise of teachers and specialists in education. This paper criticizes the contents of this document pointing out that it maintains old conceptual imprecisions concerning the pedagogical field. Such imprecisions do not contribute to overcome the problems that have accumulated in the legislation on the subject. This Resolution thus bring little advance to enhance the quality of the Brazilian basic education schools. The theoretical and prescriptive deficiencies of the Resolution demand a different understanding of the concept of pedagogy. Another curriculum option for the professional training of educators, be they teachers or education specialists, is thus needed.

Key words: Curriculum guidelines for pedagogy courses. Training policies for education professionals. Pedagogical knowledge. Pedagogical training and teacher training.

Da falta de clareza conceitual à imprecisão na definição da pedagogia e da atividade profissional do pedagogo

Resolução CNE/CP n. 1, de 15/5/2006 institui as Diretrizes Curriculares Nacionais para os cursos de graduação em pedagogia, na modalidade licenciatura. $\mathrm{O}$ artigo $2^{\circ}$ estabelece que o curso de pedagogia se destina à formação de professores para o exercício da docência em educação infantil, anos iniciais do ensino fundamental, cursos de ensino médio na modalidade Normal, cursos de educação profissional na área de serviços e apoio escolar, cursos em outras áreas que requeiram conhecimentos pedagógicos. $\mathrm{O}$ artigo $4^{\circ}$ repete o enunciado do artigo $2^{\circ}$ com uma variante: o curso de pedagogia é denominado explicitamente de licenciatura, tal como ocorre também nos artigos $7^{\circ}$, $9^{\circ}$ e 14 .

A Resolução trata, portanto, da regulamentação do curso de pedagogia exclusivamente para formar professores para a docência naqueles níveis do sistema de ensino. No parágrafo $1^{\circ}$ do artigo $2^{\circ}$, conceitua docência nos seguintes termos: "Compreende-se docência como ação educativa e processo pedagógico metódico e intencional, construído [sic] em relaçôes sociais, étnico-raciais e produtivas, as quais influenciam conceitos e objetivos da pedagogia (...)".

Está explícito no caput desse artigo a redução da pedagogia à docência, mesmo considerando-se a dubiedade presente no parágrafo 
mencionado e no parágrafo $2^{\circ}$, em que se determina que "o curso de pedagogia (...) propiciará o planejamento, execução e avaliação de atividades educativas" (grifo nosso). Já no artigo $4^{\circ}$, parágrafo único, estabelece-se que as atividades docentes, além obviamente das funçóes de magistério fixadas no caput do artigo, compreendem, também, a "participação na organização e gestão de sistemas e instituiçôes de ensino" relacionadas com atividades de planejamento, coordenação, avaliação, produção e difusão do conhecimento educacional, "em contextos escolares e não-escolares". Note-se que nesse artigo, assim como em outros ( $3^{\circ}$ e $\left.5^{\circ}\right)$, é utilizada a expressão "participação na...". Não está claro se cabe ao curso apenas propiciar competências para o professor participar da organização e da gestão ou prepará-lo para assumir funções na gestão e organização da escola. $\mathrm{O}$ parágrafo $2^{\circ}$ do artigo $2^{\circ}$, embora com redação confusa, dá a entender que o curso prepara para planejamento, execução e avaliação de atividades educativas. Seja como for, o que se diz nesse parágrafo é que o planejador da educação, o especialista em avaliação, o animador cultural, o pesquisador, o editor de livros, entre tantos outros, ao exercerem suas atividades estariam exercendo a docência.

Observa-se, desde logo, nesses artigos, que as imprecisões conceituais resultam em definiçōes operacionais muito confusas para a atividade profissional do pedagogo. De início, há uma definição explícita de que o objeto da regulamentação é um curso de licenciatura. Portanto, um curso que se situa na mesma categoria dos demais cursos de licenciatura da educação básica, deixando suposto que pode existir um curso de bacharelado em pedagogia, considerando-se a lógica da organização de cursos da universidade brasileira. Mas logo surgem as imprecisões normativas. Por um lado, estabelece-se que a licenciatura em pedagogia se destina a formar professores para educação infantil, anos iniciais, cursos normais de nível médio, cursos de educação profissional na área de serviços e apoio escolar, portanto uma licenciatura única para as modalidades de ensino mencionadas. Por outro lado, fica implícito em outros artigos que cada uma dessas modalidades seria uma "área de atuação profissional" (leia-se habilitação), conforme artigo $6^{\circ}$, alínea II, e artigo 12. Está evidente, também, a incongruência na denominação de "licenciatura em pedagogia" e não licenciatura em educação infantil e anos iniciais. Esta incongruência conduz necessariamente a uma pergunta aos legisladores: por quê, se todos os docentes são pedagogos, também não se incluem no curso de pedagogia os anos finais do ensi- 
Diretrizes curriculares da pedagogia: imprecisōes teóricas...

no fundamental e o ensino médio? Neste caso, não haveria diferença entre o curso de pedagogia e o já regulamentado Instituto Superior de Educação.

A vacilação existente no texto da Resolução, quanto à explicitação da natureza e do objetivo do curso e do tipo de profissional a formar, decorre de imprecisão conceitual com relação a termos centrais na teoria pedagógica: educação, pedagogia, docência. Com efeito, no artigo $2^{\circ}$, parágrafo $1^{\circ}$, ao se definir a docência como objeto do curso de pedagogia, um conceito derivado e menos abrangente como é a docência acaba por ser identificado com outro de maior amplitude, o de pedagogia. Há, então, uma notória inversão lógico-conceitual em que o termo principal fica subsumido no termo secundário. Em seguida, a definição parece se contradizer ao afirmar que a docência se vincula aos objetivos da pedagogia. Já no parágrafo $2^{\circ}$ do mesmo artigo, afirma-se que o curso de pedagogia propiciará "o planejamento, execução e avaliação de atividades educativas". Afinal, qual o objeto da pedagogia assumido na Resolução? Atividades educativas? Atividades docentes? A redação indica um entendimento que substitui o conceito de pedagogia pelo de docência, em conformidade com o lema da ANFOPE: "A docência é a base da formação de todo e qualquer profissional da educação e da sua identidade".

Essa imprecisão conceitual quanto ao objeto de estudo da pedagogia leva a um entendimento genérico de atividades docentes, tal como consta no parágrafo único do artigo $4^{\circ}$, em que toda e qualquer atividade profissional no campo da educação é enquadrada como atividade docente, seja essa atividade o planejamento educacional, a coordenação de trabalhos, a pesquisa e sua difusão, e seja qual for o lugar de sua realização (na escola ou não). É de se notar a confusão que o texto provoca ao não diferenciar campos científicos, setores profissionais, áreas de atuação, ou seja, uma mínima divisão técnica do trabalho, necessária em qualquer âmbito científico ou profissional, sem o que a prática profissional pode tornar-se inconsistente e sem qualidade. Além dessa apressada simplificação do campo científico da pedagogia e do exercício profissional do pedagogo, essa atividade docente, aplicada a esferas que nada têm a ver com a docência, é entendida meramente como "participação na organização e gestão de sistemas e instituições de ensino". Ou seja, a competência esperada do pedagogo-docente é saber participar da gestão, nada mais, tornando totalmente descabida a afirmação 
do artigo 14, de que os termos dessa Resolução asseguram a formação de profissionais da educação prevista no artigo 64 da LDB n. 9.394/96.

Em boa parte, decorrente dessas imprecisões conceituais de base, são verificadas outras insuficiências:

a) $\mathrm{O}$ artigo $5^{\circ}$ descreve as competências necessárias aos egressos do curso de pedagogia em 16 atribuições do docente, estabelecendo expectativas de formação de um superprofissional. São descriçōes em que se misturam objetivos, conteúdos, recomendaçōes morais, gerando superposiçōes e imprecisões quanto ao perfil do egresso. Além disso, as competências previstas neste artigo são desconectadas, distintas ou sobrepostas ao que se estabelece nos artigos $2^{\circ}\left(\$ 2^{\circ}\right)$ e $3^{\circ}$.

b) Os artigos $2^{\circ}$ e $4^{\circ}$ destinam o curso de pedagogia a formar egressos para cinco modalidades de exercício do magistério. Mas não estabelecem o percurso curricular e as modalidades de diplomação, seja para o caso dessas modalidades serem consideradas habilitações, seja para o caso em que há apenas uma titulação: licenciatura em pedagogia.

c) A alínea II do artigo $6^{\circ}$ deixa entrever a adoção, no currículo, das habilitações profissionais, inclusive as do artigo $64 \mathrm{da}$ LDB $\mathrm{n}$. 9.394/96. Com efeito, está previsto na estrutura curricular do curso um "núcleo de aprofundamento e diversificação de estudos voltado às áreas de atuação profissional priorizadas pelo projeto pedagógico das instituições..." O termo "habilitações" é mencionado no artigo 12 .

d) $\mathrm{O}$ artigo $6^{\circ}$ define a estrutura curricular em três blocos: núcleo de estudos básicos, núcleo de aprofundamento e diversificação de estudos, núcleo de estudos integradores, em que supostamente se incluem disciplinas e atividades curriculares. Mas isso não está suficientemente claro em decorrência da redação repetitiva, confusa e imprecisa.

e) $\mathrm{O}$ artigo $9^{\circ}$ exclui toda e qualquer outra modalidade de formação inicial que não sejam as estabelecidas na Resolução, deixando dúvidas quanto ao cumprimento de outros dispositivos legais em vigor, como o Parecer CNE/CP n. 9/2001 e a Resolução CNE n. 1/2002, que institui as Diretrizes Curriculares para For- 
Diretrizes curriculares da pedagogia: imprecisōes teóricas...

mação de Professores para a Educação Básica. $\mathrm{O}$ artigo 10 determina a extinção de todas as habilitações existentes decorrentes de legislação anterior, mas o texto não esclarece como fica o "aprofundamento e a diversificação de estudos voltados às áreas de atuação profissional", ou seja, quais são essas áreas de atuação profissional.

f) $\mathrm{O}$ artigo 14, que trata da formação dos profissionais da educação para administração, planejamento, supervisão etc. (artigo 64 da Lei n. 9.394/96), está em desacordo com a LDB, na qual essa formação pode ocorrer também em cursos de graduação em pedagogia. Além disso, não há garantia nenhuma, em todo o conteúdo da Resolução, de que o currículo proposto propicie, efetivamente, a preparação do "pedagogo" para o desempenho das funções mencionadas no artigo 64 da LDB. Trata-se, pois, de um artigo sem suporte legal, introduzido por conveniência dos legisladores e das associaçōes defensoras do texto da Resolução. ${ }^{1}$

A Resolução do CNE, pela precária fundamentação teórica com relação ao campo conceitual da pedagogia, pelas imprecisões conceituais e pela desconsideração dos vários âmbitos de atuação científica e profissional do campo educacional, sustenta-se numa concepção simplista e reducionista da pedagogia e do exercício profissional do pedagogo, o que pode vir a afetar a qualidade da formação de professores de educação infantil e anos iniciais. Mantém a docência como base do curso e a equivalência do curso de pedagogia ao curso de licenciatura, não se diferenciando das propostas da Comissão de Especialistas elaborada em 1999 (que incorporou as idéias defendidas pela Associação Nacional pela Formação dos Profissionais da Educação) e do Fórum de Diretores de Faculdades/ Centros de Educação das Universidades Públicas Brasileiras (FORUMDIR) (de 2005). Avança pouco no esclarecimento das dúvidas com relação a ambigüidades e confusōes já existentes na legislação, já que: a) não contribui para a unidade do sistema de formação; b) não inova no formato curricular de uma formação de educadores que atenda às necessidades da escola de hoje; c) interrompe o exercício de autonomia que vinha sendo realizado por muitas instituiçóes na busca de caminhos alternativos e inovadores ao curso em questão. Por tudo isso, não ajuda na tarefa social de elevação da qualidade da formação de professores e do nível científico e cultural dos alunos das escolas de ensino fundamental. 
Recorrência de imprecisões teóricas e conseqüências para o funcionamento da escola

O conteúdo da Resolução do CNE expressa uma visão estreita da ciência pedagógica, resultado de um equívoco teórico sem precedentes na tradição da investigação teórica da área, a subsunção da pedagogia na docência, reduzindo a essencialidade dos processos formativos a uma das dimensões do trabalho pedagógico. Esse posicionamento nega toda a tradição teórica e a estrutura lógico-conceitual da ciência pedagógica produzida desde Herbart, passando por Dilthey, Durkheim, Dewey até autores contemporâneos de vários matizes teóricos. Como já mencionado, a insuficiência epistemológica, decorrente da ausência de uma conceituação clara do campo teórico da pedagogia, originou uma Resolução cheia de imprecisóes acerca da natureza da atividade pedagógica, do campo científico da pedagogia e seu objeto, das relações entre ação educativa e ação docente, entre atividade pedagógica e atividade administrativa, comprometendo todo o arcabouço lógico e teórico da Resolução.

A discussão epistemológica envolvendo os conceitos de pedagogia e docência tem sido objeto de varias publicações (Pimenta, 1997; Libâneo, 1998; Libâneo \& Pimenta, 1999; Libâneo, 2003; Franco, 2003a). Esses autores têm argumentado que a pedagogia, obviamente, compreende a docência, pois também trata do ensino e da formação escolar de crianças e jovens, de métodos de ensino. Mas sustentam que a pedagogia não se resume a um curso, antes, a um vasto campo de conhecimentos, cuja natureza constitutiva é a teoria e a prática da educação ou a teoria e a prática da formação humana. Assim, o objeto próprio da ciência pedagógica é o estudo e a reflexão sistemática sobre o fenômeno educativo, sobre as práticas educativas em todas as suas dimensōes. Um campo científico pode constituir num curso, mas, antes, importa saber quais são suas premissas epistemológicas, seu corpo conceitual, suas metodologias investigativas. Se se admite um campo de saberes mais abrangente, é preciso admitir subcampos de conhecimentos como seriam, por exemplo, a teoria da educação, a história da educação, a organização do trabalho escolar, a didática (que trata da docência) etc.

Muitas obras e autores, clássicos e contemporâneos, dão suporte a estas formulações. O pedagogo espanhol Quintanas Cabanas escreve que a pedagogia é a ciência da educação em geral, ela apresenta as dire-

Educ. Soc., Campinas, vol. 27, n. 96 - Especial, p. 843-876, out. 2006 
Diretrizes curriculares da pedagogia: imprecisōes teóricas...

trizes a que deve submeter-se a atividade educativa: fundamentos e fins da educação, o sujeito da educação, o educador e todos os tipos e modalidades de educação (1995). O pedagogo francês Gaston Mialaret vai à mesma direção:

A pedagogia é uma reflexão sobre as finalidades da educação e uma análise objetiva de suas condições de existência e de funcionamento. Ela está em relação direta com a prática educativa que constitui seu campo de reflexão e análise, sem, todavia, confundir-se com ela. (Mialaret, 1991, p. 9)

O pedagogo alemão Schimied Kowarzik chama a pedagogia de ciência da e para a educação, portanto é a teoria e a prática da educação. Investiga teoricamente o fenômeno educativo, formula orientações para a prática a partir da própria ação prática e propõe princípios e normas relacionados aos fins e meios da educação. Franco (2003a, p. 8386), ao refletir sobre o conceito de pedagogia na perspectiva dialética, afirma que o objeto da pedagogia "é o esclarecimento reflexivo e transformador da práxis educativa", de modo que a teoria pedagógica se constitui interlocutora interpretativa das teorias implícitas na práxis do educador e, também, a mediadora de sua transformação para fins cada vez mais emancipatórios.

Essas definiçôes mostram um conceito amplo de pedagogia, a partir do qual se pode compreender a docência como uma modalidade de atividade pedagógica, de modo que a formação pedagógica é o suporte, a base, da docência, não o inverso. Dessa forma, por respeito à lógica e à clareza de raciocínio, a base de um curso de pedagogia não pode ser a docência. Todo trabalho docente é trabalho pedagógico, mas nem todo trabalho pedagógico é trabalho docente. Um professor é um pedagogo, mas nem todo pedagogo precisa ser professor. Isso de modo algum leva a secundarizar a docência, pois não estamos falando de hegemonia ou relação de precedência entre campos científicos ou de atividade profissional. Trata-se, sim, de uma epistemologia do conhecimento pedagógico.

Precisamente pela abrangência maior do campo conceitual e prático da pedagogia como reflexão sistemática sobre o campo do educativo, pode-se reconhecer na prática social uma imensa variedade de práticas educativas, portanto uma diversidade de práticas pedagógicas. Em decorrência, é pedagoga toda pessoa que lida com algum tipo 
de prática educativa relacionada com o mundo dos saberes e modos de ação, não restritos à escola. A formação de educadores extrapola, pois, o âmbito escolar formal, abrangendo também esferas mais amplas da educação não-formal e formal. ${ }^{2}$ Assim, a formação profissional do pedagogo pode desdobrar-se em múltiplas especializaçôes profissionais, sendo a docência uma entre elas.

As conseqüências lógicas dessa argumentação são extremamente claras: a) o curso de pedagogia não pode ser igual a curso de licenciatura para formação de professores de educação infantil e anos iniciais do ensino fundamental - o curso de pedagogia é uma coisa, a licenciatura outra, embora interligados; b) a base da formação do pedagogo não pode ser a docência, pois a base da formação docente é o conhecimento pedagógico; c) todo docente é um pedagogo, mas nem todo pedagogo precisa ser docente, simplesmente porque docência não é a mesma coisa que pedagogia.

A subsunção da pedagogia na docência leva a duas deduções: a) sendo a docência, e não a pedagogia, a base da organização do currículo de formação, exclui-se a formação do pedagogo especialista, já que não se faz mais a diferenciação entre as atribuições profissionais do especialista em educação e as do professor; b) a extensão do conceito de "atividades docentes" para atividades de gestão e pesquisa levou a agregar ao trabalho do professor mais duas atribuiçôes: a de investigador lato e stricto sensu, e a de gestor. ${ }^{3}$

Essas deduções mostram mais uma faceta das imprecisões epistemológicas da Resolução: a indistinção entre os termos "atividade docente" e "atividade administrativa ou organizacional" (designações correlatas à gestão, termo empregado no documento normativo). Dessa forma, fica descaracterizada não apenas a atividade pedagógica, mas também a atividade organizacional.

Observe-se, primeiramente, que uma coisa é o caráter pedagógico da docência e da gestão, ou seja, há uma necessária dimensão pedagógica da docência e da gestão, afirmação esta que se ampara plenamente no caráter abrangente do conceito de pedagogia, e que temos confirmado exaustivamente (Libâneo, 2005b, 2006). Mas daí não se pode concluir uma identificação dos conceitos de atividade docente e atividade de gestão, tal como se deduz dos textos da ANFOPE, da Comissão de Especialistas, do FORUMDir e, agora, da Resolução do CNE. As te- 
Diretrizes curriculares da pedagogia: imprecisōes teóricas...

ses defendidas pela ANFOPE sempre se centraram na idéia da docência como base da formação de todo educador. Após as críticas ao viés reducionista dessa idéia é que se introduziu entre as atividades "docentes" do pedagogo a gestão, gestão no sentido de função (área de atuação) do pedagogo. Com efeito, o documento da Comissão de Especialistas incluía como área de atuação do pedagogo a "organização e gestão de sistemas, unidades e projetos educacionais", e o projeto de Resolução do FORUMDIR mencionava em um dos artigos a formação para a "gestão educacional (...) entendida como organização do trabalho pedagógico (...)". Ao se definir a atuação do pedagogo na gestão educacional, pretendeu-se que essa definição respondesse aos críticos da ANFOPE, uma vez que abriria espaço à formação do especialista no professor, recuperando a reclamada especificidade da pedagogia. Mas agora, na Resolução do CNE, o tema da gestão foi abordado de forma modificada com relação ao que vinha sendo proposto pelas entidades. Nela, a gestão não aparece explicitamente como função do professor-pedagogo, isto é, como área de atuação do pedagogo, mas como uma competência que se espera do professor para a participação na organização e gestão de sistemas e instituições de ensino.

Que todo professor precisa aprender a participar das formas de organização e gestão da escola é algo inquestionável (cf. Libâneo, 2005a). A crítica é ao conceito de gestão presente na Resolução, à equivocada identificação entre atividade docente e atividade gestora, e entre competência do professor para participar da gestão e área de atuação profissional. Trata-se, na verdade, de conceitos distintos. $\mathrm{O}$ docente é aquele que ensina para que o aluno aprenda o que necessita para inserir-se de forma crítica e criadora na sociedade em que vive. $\mathrm{O}$ gestor é o que dispõe e coordena a utilização adequada e racional de recursos e meios, organiza situações, para a realização de fins determinados, tal como escreve Paro com relação à atividade administrativa (Paro, 1986, p. 19-20).

O gestor escolar, portanto, é alguém que no processo de trabalho escolar sabe dispor recursos por meio da racionalização do trabalho e da coordenação do esforço humano coletivo em função do fim visado, isto é, o ensino e a aprendizagem dos alunos. Docência e gestão, portanto, são dimensões da atividade pedagógica, mas não são a mesma coisa, a gestão é uma atividade-meio que concorre para a realização dos objetivos escolares sintetizados na docência. Assim sendo, não há lógi- 
ca que possa sustentar o que consta no parágrafo único do artigo $4^{\circ}$ da Resolução: "As atividades docentes também compreendem participação na organização de sistemas e instituições de ensino, englobando (...) planejamento, coordenação (...) produção e difusão do conhecimento (...)".

Já comentamos a ambigüidade do entendimento de participação na gestão como competência esperada do professor, mas, logo em seguida, a gestão se transforma em função do professor. Vê-se, pois, que a correspondência semântica entre pedagogia e gestão educacional também peca por reducionismo e, mesmo, simplificação, na mesma medida da identificação de pedagogia com docência. Não é correto, teoricamente, definir o trabalho do pedagogo especialista pela gestão, assim como é muito pouco identificar o papel do pedagogo com o docente. Trata-se de mais uma tentativa de conciliação de posições conflitantes, sem tocar na questão básica, discutida anteriormente, que é a crítica à divisão técnica do trabalho pedagógico.

Eis que chegamos ao cerne de todas as demais questóes problemáticas da Resolução do CNE, o tema da divisão do trabalho pedagógico, que irá incidir na redução do curso de pedagogia à docência e na eliminação das habilitaçôes, tal como ocorreu em propostas curriculares de algumas faculdades de educação. ${ }^{4}$

Como é sabido, há mais de 25 anos, ao mesmo tempo em que essas teses foram tomando corpo nas associações de educadores pela formação de professores, três entidades de associação profissional se autoextinguiram, a Associação Nacional de Supervisores, a Federação Nacional de Orientadores Educacionais e a Associação Nacional de Administração Escolar. Paralelamente, muitas Secretarias de Educação retiraram das escolas ou deixaram de contratar coordenadores pedagogos com formação específica, prejudicando a gestão curricular e pedagógico-didática. Que motivaçôes levaram os educadores a extinguir suas entidades profissionais? Por que se acabaram as habilitações em alguns cursos de pedagogia? Quais terão sido os ganhos e os prejuízos dessa auto-extinção para as escolas, para os alunos e para as famílias? Que razões levaram a essas medidas?

Já deixamos claro que a Resolução mantém a docência como eixo distintivo do currículo de formação do "pedagogo", 5 o que significa fazer equivaler o curso de pedagogia a um curso de licenciatura. Mencionamos anteriormente a falta de embasamento na teoria pedagógica da 
Diretrizes curriculares da pedagogia: imprecisōes teóricas...

principal tese em que se sustenta a Resolução. O que justificaria tamanha convicção de um numeroso grupo de educadores que há anos sustenta a tese da docência como base da formação de todo educador?

\section{A crença na docência como base comum da formação profissional}

A origem dessa crença coincide com o movimento político no meio dos intelectuais da educação, mais precisamente o ano de 1980, em que foi realizada a I CBE e criado o Comitê Pró-Formação do Educador. A tese central desse movimento - "a docência constitui a base da identidade profissional de todo educador" (Encontro Nacional, 1983) - consumouse como bandeira da ANFOPE, que perpetuou o mote e acabou por difundi-lo entre os educadores de forma pouco crítica, uma vez que raramente os pressupostos teóricos da tese foram justificados. Entretanto, as poucas tentativas de proceder a essa justificativa fazem crer que sua origem está na crítica à divisão técnica do trabalho na escola.

A análise da documentação publicada pelas associações de educadores permite concluir que a argumentação não tem apoio na teoria pedagógica, mas na sociologia. A organização da escola sob o capitalismo implicaria uma degradação do trabalho profissional do professor. A formação no curso de pedagogia seria fragmentada, pois formaria de um lado pedagogos, que planejam e pensam, e de outro os professores, que executam, dentro da lógica da divisão técnica do trabalho segundo a qual, na sociedade capitalista, predomina a divisão entre proprietários e não-proprietários dos meios de produção. A essas duas classes sociais corresponde uma divisão social do trabalho em que uma se ocupa do trabalho intelectual, outra do trabalho manual. Há uma cisão entre o trabalhador e os meios ou instrumentos de trabalho, em que esses meios são providos pelos gestores do processo de produção. Há uma classe que pensa, desenvolve os meios de trabalho, controla o trabalho; e outra classe que faz serviço prático, cumpre determinações do gestor, fundando a desigualdade social. A divisão social do trabalho, expressão das relações capitalistas de produção, e que se manifesta na organização do processo de trabalho, reproduz-se em todas as instâncias da sociedade, inclusive nas escolas, onde haveria dois segmentos de trabalhadores opostos entre si, os especialistas (diretor, coordenador pedagógico) e os professores, instaurando a desigualdade e promovendo a desqualificação do trabalho dos professores. E como se elimina essa fragmentação? Eli- 
minando a divisão de tarefas que está na base da fragmentação do trabalho pedagógico e transformando todos os profissionais da escola em professores. Foi natural, daí, chegar à tese da docência como base do currículo de formação dos educadores, pela qual o curso de pedagogia passa a ter como função essencial a formação de docentes.

Esse arrazoado aparece de modo exemplar na Exposição de Motivos que acompanha a Resolução n. 207/1984, da Universidade Federal de Goiás, que fixa o currículo do curso de pedagogia, definido como licenciatura para formar professores das matérias pedagógicas do curso normal e das séries iniciais do ensino de $1^{\circ}$ grau. Nesse currículo, foram totalmente excluídas as habilitações que, à época, constavam da legislação (Parecer n. 252 e Resolução n. 2/69 do CFE). A Resolução da UFG, além de mencionar explicitamente o vínculo com as teses do Comitê Pró-Formação do Educador, foi provavelmente o primeiro documento normativo sobre o que se acreditava ser o novo formato do curso de pedagogia debatido naquele Comitê. $\mathrm{O}$ argumento para transformar a pedagogia num curso de formação de professores, sem as habilitações, é muito claro. Conforme se lê na Exposição de Motivos, a expansão de matrículas nas escolas de ensino fundamental, fruto da política educacional da época, requeria distribuir de modo mais racional as tarefas de escolarização entre os profissionais da educação (orientador educacional, administrador escolar, supervisor escolar e inspetor escolar), deixando aos professores as tarefas de execução do ensino. Dessa forma, a política educacional do Estado

(...) negou o saber e a competência dos professores no desempenho dessas funçōes (...). Transformado num mero executor do que é pensado e decidido por outrem, o professor é cada vez mais afastado de uma compreensão do seu processo de trabalho como um todo, bem como de sua condução. Essa fragmentação e hierarquização do trabalho pedagógico é, portanto, um importante meio de controle da educação pelo Estado (...).

Segue-se, no documento, a explicitação de que o curso de pedagogia deve formar o pedagogo, o qual deve ser, antes de tudo, um professor, não fazendo mais sentido a formação de técnicos/especialistas (sic), já que sua presença na escola fragmenta o processo de escolarização, expropria o saber e a competência dos professores, separa o que pensa, decide e planeja do que executa e, portanto, "sua existência é contra a democratização do processo de trabalho no interior da escola". 
Diretrizes curriculares da pedagogia: imprecisōes teóricas...

Com base nesta argumentação, são indicadas as disciplinas e atividades curriculares, inclusive as disciplinas encarregadas do conhecimento totalizante da escola (sociologia, psicologia, etc.) e das formas de organização do trabalho pedagógico, o qual contribuirá para que "esse novo professor tenha condições de participar efetivamente da vida da escola e de exercer temporariamente as funções de direção e coordenação-geral ou de área”. Como se pode constatar são exatamente os termos que acabaram por formar o arcabouço das teses da ANFOPE, da Comissão de Especialistas e, agora, da Resolução n. 1, de 15/5/2006, do CNE.

Essas idéias haviam sido anteriormente desenvolvidas com posições teóricas bem definidas no artigo "Pedagogia e educação ou de como falar sobre o óbvio", de José Miguel Rasia, publicado nos Cadernos CEDES n. 2 (Rasia, 1980). Após expor a divisão social e técnica do trabalho no capitalismo, em que se diferenciam dois grupos no interior do processo da produção social, os que executam e os que controlam o processo, escreveu o autor:

(...) a organização despótica do trabalho na sociedade capitalista se reproduz no interior da organização escolar (...). Entendemos por processo de produção escolar o processo que se dá no interior da organização escolar do qual participam alunos, professores, pedagogos, conteúdos (ciência + ideologia) e comportamentos e que tem como resultado final um certo tipo de homem que reproduz em si as determinaçōes da sociedade capitalista (...). O exame empírico da escola nos permite visualizar no interior do processo de produção escolar uma especialização dos trabalhadores em funçôes específicas. De um lado, os pedagogos propriamente ditos e de outro os professores. Penetrando mais a fundo na observação da dinâmica escolar, vemos que aos primeiros correspondem as funçôes de controle e administração, de organização do processo de produção escolar. Aos professores correspondem as funções de execução de um certo planejamento institucional (...). Neste sentido, poderíamos afirmar que os pedagogos enquanto "administradores" da educação se esforçam para orientar, supervisionar e administrar o processo de produção escolar tendo em vista sua continuidade. Isso implica o exercício de um certo despotismo, de uma certa dominação sobre o conjunto daquilo que, em linguagem pedagógica, chamamos de corpo docente e não só a este, mas também ao corpo discente. Em uma palavra, ao universo escolar como um todo (...). O que devemos estabelecer como tarefas para o pedagogo, hoje - quando falo em pedagogo estou me referindo a todo educador -, são duas questōes que me parecem fundamentais na análise que se faz da 
escola: o poder de decidir e de reorganizar o trabalho pedagógico; o poder de trazer para a sala de aula as grandes questôes do cotidiano da classe trabalhadora. (p. 19-24)

O tema volta a ser tratado em 1990 (V Encontro Nacional da CONARCFE) em que a adoção da base comum nacional do currículo foi justificada como "instrumento de luta contra a degradação da formação do profissional da educação", provocada pela fragmentação do trabalho sob o capitalismo, caracterizada pela separação entre concepção do trabalho e sua realização, e pelo controle do trabalho de execução de quem detém o conhecimento do processo de trabalho. São formulações que dão suporte teórico ao mote cunhado em 1983, no qual se sustenta a base comum nacional dos cursos de formação de educadores: "Todas as licenciaturas (pedagogia e demais licenciaturas) deverão ter uma base comum: são todos professores; a docência constitui a base da identidade profissional de todo educador". ${ }^{6}$ Os documentos oficiais dos movimentos, publicados após 1990 - Comissão Nacional pela Reformulação dos Cursos de Formação do Educador e Associação Nacional pela Formação dos Profissionais da Educação -, apenas reiteram o mote, sem apresentar novas contribuições para a discussão epistemológica da identidade científica e profissional da pedagogia.

Há muitas maneiras de discutir essas questôes, especialmente a da relação entre as formas organizacionais do processo capitalista de produção e as formas de organização do trabalho em instituiçôes. Há um outro caminho para se compreender a relação entre as formas de gestão na empresa e as formas de gestão na escola, que leva a conclusões diferentes do que foi exposto. A escola será, efetivamente, um local de trabalho capitalista? É fato que o sistema de produção capitalista põe a escola a seu serviço para atender necessidades de sua própria manutenção, especialmente para produzir trabalhadores, de forma que ela cumpre determinados papéis para o funcionamento da organização capitalista da produção. E admissível que a organização escolar contenha também elementos do processo capitalista de organização do trabalho. Entretanto, não se pode deduzir disso que a escola passe a constituir-se exclusivamente como local de trabalho capitalista. Se isso fosse possível, a escola seria considerada um lugar de produção de mercadorias, valendo aí o raciocínio segundo o qual a produção de trabalhadores (o que faz a escola) seria idêntica ao processo de produção de mercadorias. Há de se considerar que os professores, como também os especialis- 
Diretrizes curriculares da pedagogia: imprecisões teóricas...

tas, que atuam na escola, não são agentes diretos do capital, nem os alunos mercadorias a serem produzidas. Isso leva a distinguir produção de coisas e produção de seres humanos como processos não-idênticos, ainda que estruturas organizacionais sejam planejadas para que uma possa estar a serviço de outra. Além do mais, se convém ao capitalista produzir trabalhadores assalariados automatizados, isso não significa que a subjetividade do trabalhador seja sempre subjugada em função do capital. O que ocorre, pois, é que o trabalho escolar tem sua especificidade, ainda que não descolada dos seus vínculos com a organização social e econômica da sociedade. ${ }^{7} \mathrm{O}$ trabalho pedagógico escolar tem uma natureza não-material, não se aplicando a ele, de modo pleno, o modo de produção capitalista. O conhecimento como objeto de trabalho na escola é inseparável no ato de produção, e esta capacidade potencial ninguém retira da pessoa que conhece. Isso significa que os resultados do processo de trabalho escolar, bem como as formas de organização interna, não estão absolutamente preordenados pelo capital. Se há uma especificidade do trabalho pedagógico escolar, há também uma especificidade das formas de organização do trabalho pedagógico, por mais que estas possam ser permeadas por influxos da organização geral do capitalismo.

A explicação do surgimento da desigualdade social pela divisão do trabalho não exclui outros fatores geradores da desigualdade. Além disso, conquanto a escola não produza as desigualdades básicas (elas são anteriores), pode gerar em seu interior outras desigualdades, como o tratamento diferenciado de homem e mulher, a discriminação social, a discriminação étnica, a exclusão de crianças que não conseguem aprender, o insucesso na aprendizagem por causa de uma professora despreparada. Dada a natureza da instituição escolar, os elementos presentes nas relações capitalistas de produção não incidem nela de forma igual. Nas atuais condições de funcionamento da escola, a divisão técnica do trabalho, expressa na suposta fragmentação entre trabalho de especialistas e de professores, não se constitui o problema central. Ao contrário, pode ser uma necessidade, pois um especialista profissionalmente bem preparado pode ter mais êxito pedagógico no enfrentamento das desigualdades promovidas pela escola: as práticas de exclusão social, de exclusão pedagógica, de marginalização cultural, de discriminação racial, de produção do fracasso escolar etc. Cabe, pois, perguntar o que será pior: (a) a escola ter uma coordenadora pedagógica bem formada e competente para prestar auxí- 
lio efetivo às professoras, propiciar condições de êxito escolar dos alunos, ou (b) fazer uma criança fracassar na aprendizagem porque não há ninguém na escola capacitado e com formação específica, para ajudar a professora a melhorar seu trabalho e ampliar as chances de inclusão dos alunos?

O dilema posto hoje aos educadores que valorizam a escola e a importância da formação de professores e especialistas é: Repetir ou criar? Conservar teses arraigadas ou tentar outros caminhos? O que estamos sugerindo é que a origem do mote da docência como base da formação de todo educador repercute nas imprecisões e ambigüidades da Resolução do CNE. Haverá ainda razōes para sustentar este mote? Trata-se de um fenômeno sociológico a investigar: $\mathrm{O}$ que explica essa fixação, sem nenhuma alteração, num discurso produzido há mais de 25 anos? Que razões têm levado educadores a prender-se tão fortemente a bordóes cuja principal característica é a interminável repetição? O que explica a dificuldade de segmentos de educadores em romper com essa rede de sugestão coletiva criada por uma associação em torno de uma crença?

\section{Conseqüências para a formação de professores}

As leis destinam-se a dar forma a modos de estruturação das atividades humanas e sociais instauradas na realidade, e assim regulamentar, por exemplo, um serviço público em função de finalidades e aspirações sociais. É certo que os problemas da educação básica em nosso país não resultam apenas da impropriedade ou ineficácia da legislação, devendose considerar outros fatores como: a estrutura e o funcionamento dos órgãos (federais, estaduais e municipais) encarregados das políticas educacionais e da gestão do sistema de ensino; as universidades e outras instituiçōes formadoras de professores; a insuficiente ou inadequada contribuição das associações e entidades profissionais ligadas aos educadores etc. A legislação, entretanto, tem também um papel significativo no funcionamento dos sistemas de ensino e das práticas escolares.

As imprecisóes conceituais e ambigüidades apontadas na Resolução do CNE trazem conseqüências graves para a formação profissional, entre elas: a) a limitação do desenvolvimento da teoria pedagógica decorrente da descaracterização do campo teórico-investigativo da pedagogia e dos campos de atuação profissional do pedagogo especialista; b) o desaparecimento dos estudos de pedagogia no curso de pedagogia, 
Diretrizes curriculares da pedagogia: imprecisōes teóricas...

levando ao abandono dos fundamentos pedagógicos necessários à reflexão do professor com relação à sua prática; c) o inchamento de disciplinas no currículo, provocado pelas excessivas atribuições previstas para o professor, causando a superficialidade e acentuando a precariedade da formação; d) O rompimento da tradição do curso de pedagogia de formar especialistas para o trabalho nas escolas (diretor de escola, coordenador pedagógico), para a pesquisa, para atuação em espaços não-escolares; e) a secundarização da importância da organização escolar e das práticas de gestão, retirando-se sua especificidade teórica e prática, na qualidade de atividades-meio, para assegurar o cumprimento dos objetivos da escola.

A primeira consequiência é que a descaracterização do campo teórico da pedagogia e da atuação profissional do pedagogo limita e enfraquece a investigação no âmbito da ciência pedagógica. Não se estuda pedagogia nos cursos de pedagogia, a teoria pedagógica e a investigação de formas específicas de ação pedagógica estão ausentes das faculdades de educação. Em boa parte delas, quem emite juízos sobre questões de pedagogia hoje são os sociólogos, os cientistas políticos, os especialistas em políticas educacionais, os psicólogos, não os pedagogos. E, pior, com as mudanças curriculares centradas na docência, não são mais formados os pedagogos para pensar e formular políticas para as escolas, analisar criticamente inovações pedagógicas, formular teorias de aprendizagem, investigar novas metodologias de ensino, concepções e procedimentos, avaliação escolar etc. Não são mais formados administradores educacionais, diretores de escola, profissionais para a gestão do currículo e promoção do desenvolvimento profissional dos professores na escola, profissionais que ajudem os professores nas suas dificuldades com a aprendizagem dos alunos. É, em parte, por isso que o campo da educação não tem conseguido sequer um consenso mínimo sobre políticas para a escola básica, sem conseguir até hoje formular um sistema integrado e articulado de formação de educadores.

Em segundo lugar, a ausência da teoria pedagógica na formação do licenciado empobrece a contribuição da análise crítica da educação que se pratica nas instituições de formação e nas instituições escolares. A pedagogia, como ciência da educação auxiliada por diferentes campos do conhecimento, estuda criticamente a educação como práxis social, analisando-a, compreendendo-a, interpretando-a em sua complexidade, propondo outros modos e processos para sua concretização, com vistas à construção de uma sociedade justa e igualitária. Franco (2003b) escreve: 
Subsumir a pedagogia à docência é não somente produzir um reducionismo ingênuo a esta ciência, como também ignorar a enorme complexidade da tarefa docente, que para se efetivar requer o solo dialogante e fértil de uma ciência que a fundamente, que a investigue, compreenda e crie espaço para sua plena realização.

A terceira conseqüência diz respeito ao recrudescimento da precariedade da formação, com conseqüências para a qualidade do ensino. Há dois problemas conexos que podem estar comprometendo a qualidade da formação de muitos cursos: a) sobrecarga disciplinar no currículo para cobrir todas as tarefas previstas para o professor; b) ausência de conteúdos específicos das disciplinas do currículo do ensino fundamental. É difícil crer que um curso com 3.200 horas possa formar professores para três funções que têm, cada uma, sua especificidade: a docência, a gestão, a pesquisa, ou formar, ao mesmo tempo, bons professores e bons especialistas, com tantas responsabilidades profissionais a esperar tanto do professor como do especialista. Insistir nisso significa implantar um currículo inchado, fragmentado, aligeirado, levando ao empobrecimento da formação profissional. Para se atingir qualidade da formação, ou se forma bem um professor ou se forma bem um especialista, devendo prever-se, portanto, dois percursos curriculares articulados entre si, porém distintos.

Em boa parte dos atuais cursos há quase que total ausência no currículo de conteúdos específicos (de português, ciências, matemática, história etc.), existindo apenas as metodologias. Como formar bons professores sem o domínio desses conhecimentos específicos? Essa exigência se amplia perante as mais atuais concepções pedagógicas, em que o ensino está associado ao desenvolvimento das capacidades cognitivas dos alunos por meio dos conteúdos, ou seja, aos processos do pensar autônomo, crítico, criativo. Não se trata mais de passar conhecimentos, mas de desenvolver nos alunos capacidades e habilidades mentais referentes a esses conhecimentos. Está sendo requerido dos professores que dominem os conteúdos mas, especialmente, o modo de pensar, raciocinar e atuar próprio de cada disciplina, dominar o produto junto com o processo de investigação próprio de cada disciplina. Como fazer isso sem os conteúdos específicos?

A quarta conseqüência refere-se às perdas que sofrerão as escolas sem a formação específica de administradores escolares, coordenadores pedagógicos, psicopedagogos no curso de pedagogia. Muitos professo- 
Diretrizes curriculares da pedagogia: imprecisōes teóricas...

res e pesquisadores reconhecem o valor de uma gestão escolar competente a serviço da aprendizagem dos alunos, incluindo a assistência pedagógico-didática aos professores e alunos. Não será preciso muito esforço para concluir que há na escola um conjunto de atividades de coordenaçãa e gestão que, pela sua complexidade, requerem formação específica (cf. Libâneo, 2005b). Vejamos:

- Coordenação dos procedimentos de elaboração do projeto pedagógico-curricular e de outros planos e projetos da escola, implicando diagnósticos, prospecções, perfil de aluno a ser formado, critérios de qualidade cognitiva e operativa, expectativas de formação com relação a competências cognitivas, procedimentais, éticas.

- Coordenação de todas as ações pedagógicas, curriculares, didáticas e organizacionais, relacionadas com o desenvolvimento do ensino e da aprendizagem.

- Assistência pedagógico-didática direta e assessoramento aos professores, por meio de observação de aulas, entrevistas, reunióes de trabalho conjunto entre os professores, atividades de pesquisa etc.

- Suporte nas práticas de organização e gestão, implicando exercício de liderança, criação e desenvolvimento de ambiente de trabalho cooperativo, gestão das relações interpessoais, ações de desenvolvimento pessoal e profissional dos professores.

- Criação e coordenação de estrutura de apoio direto a alunos com dificuldades transitórias nas aprendizagens de leitura, escrita e cálculo, para além do tempo letivo, e organização do atendimento a alunos com necessidades educativas especiais.

- Ações de integração dos alunos na vida da escola e da sala de aula, bem como trabalho com as famílias e a comunidade, requerendo-se a compreensão e análise dos aspectos socioculturais e institucionais que impregnam a escola.

- Acompanhamento e avaliação do desenvolvimento do projeto pedagógico-curricular e dos planos de ensino, da atuação do corpo docente, da aprendizagem dos alunos.

Intelectuais e militantes do campo educacional que efetivamente conhecem o cotidiano das escolas compreenderão muito bem que a pre- 
paração para essas tarefas não se viabiliza com uma ou duas disciplinas. Ao contrário, requer formação específica, num curso de bacharelado, independentemente de experiência docente prévia, já que as interfaces entre profissionais-especialistas e profissionais docentes dar-se-ão no embate prático das situações concretas.

A quinta conseqüência refere-se à secundarização da organização e gestão nas escolas em decorrência da destinação do curso de pedagogia exclusivamente para a formação de professores. A organização e gestão das escolas não pode ser um trabalho improvisado, pois ela é requisito para realizar os objetivos da escola. Pesquisas que buscam saber que características distinguem uma escola, quanto ao nível da qualidade de ensino, mostram que o modo como a escola funciona - suas práticas de organização e gestão, a capacidade de liderança dos dirigentes, a assistência aos professores e alunos, a consistência do projeto pedagógico-curricular, as oportunidades de reflexão e trocas de experiências entre os professores, um currículo bem estruturado e bem coordenado - faz diferença com relação aos resultados escolares dos alunos. São razões suficientes para se valorizar a formação específica de diretores de escola e coordenadores pedagógicos, em função da ajuda que podem dar aos professores e à melhoria da aprendizagem dos alunos. Escreve Paro:

Se estamos convencidos de que a maneira de a escola contribuir para a transformação social é o alcance de seus fins especificamente educacionais, precisamos dotá-la de racionalidade interna necessária à efetivação desses fins (...). A administração escolar precisa saber buscar, na natureza própria da escola e dos objetivos que ela persegue, os princípios, os métodos e as técnicas adequadas ao incremento de sua racionalidade. (Paro, 1986, p. 136)

\section{Conseqüências para o funcionamento das escolas}

As considerações que vimos fazendo objetivam mostrar que o sistema de formação de educadores como um todo, as políticas, as diretrizes e a legislação precisam estar a serviço da elevação do nível de qualidade das escolas. Os problemas da formação profissional de educadores no Brasil são institucionais, históricos, legais etc., mas eles resultam de uma problemática que está em outro lugar: no mundo real e concreto das escolas, situadas, por sua vez, num mundo em mudança. As pesquisas que tratam da formação profissional revelam uma ferida aberta que é o 
Diretrizes curriculares da pedagogia: imprecisōes teóricas...

descompasso entre a definição de dispositivos legais e a realidade cotidiana das escolas. Todos sabem que a escola no Brasil padece de muitas carências e de muitos problemas crônicos que contribuem para o rebaixamento da qualidade do ensino - pobreza das famílias, baixo salário dos professores, desvalorização social da profissão de professor, precárias condiçôes físicas e materiais das escolas, repetência, defasagem idade-série escolar, dificuldades de aprendizagem dos alunos. Constata-se que boa parte do professorado não tem domínio de conteúdos e de metodologias, falta-lhes cultura geral de base, têm notórias dificuldades de leitura e produção de textos, estão despreparados para lidar com a diversidade social e cultural e com problemas típicos da realidade social de hoje como a violência, a influência das mídias, a indisciplina. São conhecidos também outros fatores que intervêm negativamente no trabalho da sala de aula como a desmotivação, a rotatividade, o absenteísmo e o estresse de professores. Junto com isso tudo, é notória a fragilidade das formas de organização e gestão da escola, que tornam ainda mais difíceis as ações efetivas em vista de uma escola e de um ensino de qualidade.

Há outras incidências do contexto sociocultural em que se situam as escolas, tais como as mudanças no mundo do trabalho, da política, da ética das relações sociais. A intensificação da urbanização e a complexificação da vida na cidade ampliam as responsabilidades da escola na formação da cidadania. A democratização do acesso à escolarização, a migração interna associada à expansão urbana desordenada, resultando na diversidade social e cultural dentro da escola, tornando heterogêneas as necessidades individuais e sociais a atender. Os influxos da sociedade da informação, em especial dos meios de comunicação, produzem mudanças comportamentais na juventude e afetam as formas de aprender. São desafios de um mundo em mudança que atingem diretamente as escolas e o trabalho dos professores.

Não é a reformulação legal do curso de pedagogia que trará a solução para esses problemas. Todavia, parte das confusōes da legislação e das dificuldades em se obter consenso sobre os formatos curriculares decorre da falta de sensibilidade à problemática que atinge as escolas. Pesquisadores, intelectuais, legisladores talvez não estejam sabendo vincular as políticas de formação de professores às políticas para a escola e para a aprendizagem dos alunos, e uma das razōes disso está no seu distanciamento das questôes concretas que envolvem o funcionamento da escola e o trabalho dos professores (cf. Libâneo, Oliveira \& Toschi, 2005). É possível, 
então, que o discurso em defesa da docência como base para o currículo de formação de todos os profissionais da educação e a eliminação das habilitaçôes tenha prescindido da prática. Foi tão necessário politicamente defendê-lo, para sustentar a mística de um movimento, que mais uma vez a realidade foi punida por não estar de acordo com a teoria. Tem faltado, portanto, no debate sobre a formação de educadores e os lugares dessa formação, uma fidelidade maior à realidade, à prática, àquilo que efetivamente acontece nas escolas. As idéias não são simplesmente produtos de outras idéias, mas são provocadas ou alteradas pela experiência material, pela prova da prática.

Os desafios postos pela realidade social precisam ser assumidos pelas escolas e pelos professores. Porém, para fortalecer a escola e os professores são necessários, também, os pedagogos-especialistas, com formação específica. É certo que a melhoria do ensino e do trabalho dos professores não depende somente da formação de pedagogos-especialistas, mas estes profissionais podem proporcionar às escolas uma ajuda inestimável para pensar e atuar com relação à definição de objetivos sociais e culturais para a escola, capacidades a formar, competências e habilidades cognitivas, formatos curriculares, metodologias de ensino, práticas de organização e gestão na escola, níveis de desempenho escolar esperados dos alunos.

Uma base teórico-crítica para uma pedagogia engajada nos problemas reais

A realidade atual mostra um mundo ao mesmo tempo homogêneo e heterogêneo, num processo de globalização e individualização, afetando sentidos e significados de indivíduos e grupos, criando múltiplas culturas, múltiplas relações, múltiplos sujeitos. Se, de um lado, a pedagogia centra suas preocupações na explicitação de seu objeto, dirigindo-se ao esclarecimento intencional do fenômeno do qual se ocupa, por outro, esse objeto requer ser pensado na sua complexidade.

Os educadores, tanto os que se dedicam à pesquisa quanto os envolvidos diretamente na atividade docente, enfrentam uma realidade educativa imersa em perplexidades, crises, incertezas, pressões sociais e econômicas, relativismo moral, dissoluções de crenças e utopias. Pedese muito da educação em todas as classes, grupos e segmentos sociais, 
Diretrizes curriculares da pedagogia: imprecisōes teóricas...

mas há cada vez mais dissonâncias, divergências, numa variedade imensa de diagnósticos, posicionamentos e soluções. Talvez a ressonância mais problemática disso se dê na sala de aula, onde decisóes precisam ser tomadas e açōes imediatas e pontuais precisam ser efetivadas visando a promover mudanças qualitativas no desenvolvimento e na aprendizagem dos sujeitos. Pensar e atuar no campo da educação, como atividade social prática de humanização das pessoas, implica a responsabilidade social e ética de dizer não apenas por que fazer, mas o quê e como fazer. Isso envolve necessariamente uma tomada de posição pela pedagogia, na qualidade de dispositivo teórico e prático de viabilização das práticas educativas.

\section{O sentido do pedagógico}

É intrínseco ao ato educativo seu caráter de mediação no desenvolvimento dos indivíduos no interior da dinâmica sociocultural de seu grupo, sendo o conteúdo dessa mediação a cultura que vai se convertendo em patrimônio do ser humano, isto é, os saberes e modos de ação. Trata-se, pois, de entender a educação como assimilação e reconstrução da cultura e a pedagogia como prática cultural, forma de trabalho cultural, que envolve uma prática intencional de produção e internalização de significados para a constituição da subjetividade. A pedagogia, justamente, opera, viabiliza essa mediação cultural por meio de várias instituiçōes, agentes e modalidades, entre elas a educação escolar. Para isso, define objetivos, finalidades, formas de intervenção, pelo que dá uma direção de sentido, um rumo, ao processo educacional, tendo em vista a atuação dos educandos em uma sociedade concreta (Libâneo, 2003).

É disto que trata a pedagogia: a mediação de saberes e modos de agir que promovam mudanças qualitativas no desenvolvimento e na aprendizagem das pessoas, objetivando ajudá-las a se constituírem como sujeitos, a melhorarem sua capacidade de ação e suas competências para viver e agir na sociedade e na comunidade. Desse modo, todo profissional que lida com a formação de sujeitos, seja em instituiçōes de ensino, seja em outro lugar, é um pedagogo. Entretanto, na realidade brasileira, as instituiçóes de ensino formal ganham destacada importância, razão pela qual é crucial saber o que a pedagogia pode fazer pelas escolas e pelos professores. Muitas condiçôes precisam ser atendidas com relação aos níveis de desenvolvimento e aprendizagem dos alunos, à seleção e organização dos conteúdos, às formas de estimulação e mo- 
tivação, ao espaço físico e ambiental, às formas de organização e gestão da escola e da sala de aula, aos instrumentos de avaliação da aprendizagem, aos meios de redução de dificuldades de aprendizagem etc.

Que fique claro: um professor também é um pedagogo e o melhor que pode fazer é formar, criar e constituir sua própria pedagogia. A formação permanente do professorado requer uma pedagogia crítica engajada, uma pedagogia que possibilite a compreensão teórica dos problemas, as instrumentalidades de ação docente e a efetiva solução dos graves problemas que atingem o sistema de ensino brasileiro.

A formação inicial e continuada requer dos professores uma teoria capaz de fazê-los compreender sua prática e revitalizá-la, o domínio de conteúdos e de processos formativos, o desenvolvimento de convicções e atitudes, pelos quais se tornam habilitados a ajudar os alunos em suas aprendizagens. Isso significa fazer pedagogia, ter uma pedagogia. $\mathrm{O}$ que se espera de um professor é que, pelos conhecimentos que adquire e pela preparação para a atividade docente prática, vá formando um pensamento pedagógico e um modo de agir pedagógico próprios. Conforme Franco (2006, p. 27), os saberes da pedagogia podem tornar melhores os professores: "O professor que puder construir uma nova profissionalidade pedagógica terá mais condições de engajar-se critica e criativamente em seu coletivo profissional e reinventar assim as negociações políticas de seu ser e estar na profissão".

Nenhum investigador e nenhum educador prático poderão, pois, evadir-se da pedagogia, pois o que fazemos quando intentamos educar pessoas é efetivar práticas pedagógicas que irão constituir sujeitos e identidades. Um posicionamento pedagógico requer uma investigação das condições escolares atuais de formação das subjetividades e identidades para verificar onde estão as reais explicações do sentimento de fracasso, de mediocridade, de incompetência, que vai tomando conta do alunado. Não haverá mudanças efetivas enquanto a elite intelectual do campo científico da educação e os educadores profissionais não reconhecerem algo muito simples: escola existe para formar sujeitos preparados para sobreviver nesta sociedade; para isso precisam da ciência, da cultura, da arte, precisam saber coisas, saber resolver dilemas, ter autonomia e responsabilidade, saber dos seus direitos e deveres, construir sua dignidade humana, ter uma auto-imagem positiva, desenvolver capacidades cognitivas para apropriar-se criticamente dos benefícios da ciência e da tecnologia em favor do seu trabalho, da sua vida 
Diretrizes curriculares da pedagogia: imprecisōes teóricas...

cotidiana, do seu crescimento pessoal. Por isso, não é suficiente, quando falamos em práticas escolares, a análise globalizante do problema educativo, nem basta apenas uma visão política. Aos aspectos externos que explicitam fatores determinantes da realidade escolar é necessário agregar os meios educativos, os instrumentos de mediação que são os dispositivos e métodos de educação e ensino, ou seja, a didática, para os quais se necessita do aporte de outros campos de saberes.

\section{As dimensões de abordagem da pedagogia}

O desenvolvimento teórico da pedagogia desde a segunda metade do século XIX, especialmente na Alemanha, mas com repercussão em outros países europeus, assegura a validez de se atribuir a ela um sentido amplo de ciência da educação, ou seja, um campo de conhecimentos que trata da teoria e da prática da educação e da formação, não restrito ao âmbito da instrução escolar. Esta afirmação de modo algum vem obscurecer o esforço quase natural dos educadores que buscam a aplicação de uma pedagogia à escola; apenas quer acentuar que a reflexão pedagógica ultrapassa uma dimensão apenas metodológica ou metódica do fazer as coisas na direção do pensá-las. Faz-se a crítica à subsunção da pedagogia pela docência em razão de que é a pedagogia que traz os princípios de referência, sempre reavaliados em face de realidades concretas, ${ }^{8}$ em busca de certos critérios de condução da ação na qual se engajam os ensinantes e seus formadores, algo que Durkheim (1967) já havia chamado de "teoria prática", expressão também utilizada por Suchodolski (1977, p. 27). A pedagogia representa, com relação aos modos de educar e formar, incluindo o ensino, como que um programa de ação, depois que já foi recolhendo no seu desenvolvimento histórico tantas idéias e experiências, tanta arte e ciência, tanta experienciação e reexperienciação. Pedagogia, então, nem é só uma doutrina educacional nem só uma prescrição didática, ela se moverá entre a teoria e a prática, pois que educar e ensinar sempre estão a requerer, ao mesmo tempo, um projeto que encarna um ideal do humano e da sociedade desejada e um modo de realizá-lo com o outro, seja a criança, o adulto, o aluno, o profissional. Este posicionamento sobre a pedagogia é o incômodo necessário aos professores mais tendentes ao fazer prático, para que a ação docente não perca sua intencionalidade, seus propósitos éticos e edificantes, a consideração às características individuais, sociais e 
culturais dos alunos. Ou seja, a pedagogia é a educação que se pensa e se faz, com legitimidade para dizer o que é melhor fazer quando se educa. Suchodolski escreve que a pedagogia, como ciência teórica, investiga os fatores modeladores do homem em seu desenvolvimento histórico, isto é, por que os indivíduos são concretamente o que são e quais são as possibilidades de modificá-los; como ciência prática, busca as diretrizes sobre como transformar os indivíduos com base na experiência da humanidade e nas necessidades presentes. E conclui: "Só por meio da compreensão de como se formam os indivíduos podemos adquirir os conhecimentos indispensáveis para a atividade prática neste aspecto, (...) criando uma teoria prática e uma prática teórica (...)" (1977, p. 27).

Sem um programa de ação, sem uma direção de sentido da docência, sem uma teoria prática orientadora, um professor terá dificuldade de dizer em razão de que faz uma exigência ao aluno, atribui uma nota, aprova ou desaprova uma conduta.

Essa compreensão ampla da pedagogia permite, também, distinguir três dimensōes de sua abordagem: a epistemológica, a dos saberes práticos e a dos saberes disciplinares. ${ }^{9}$ Trata-se, obviamente, de distinções úteis para análise e explicitação dos elementos contidos na natureza da pedagogia.

A dimensão epistemológica constrói-se pela reflexão crítica sobre o exercício das práticas e das intencionalidades que impregnam as ações pedagógicas cotidianas, num processo contínuo de auto-esclarecimento, colocando a ação pedagógica sob a responsabilidade crítica. A dimensão prática - o modo de agir pedagógico articulando saberes e fazeres, isto é, os saberes pedagógicos - constitui-se no campo tensional entre o conhecimento educacional, os saberes da prática e as solicitaçóes advindas das novas intencionalidades que vão se organizando em processo. Por sua vez, a dimensão disciplinar consolida-se quase que como uma síntese, a partir dos saberes tornados inteligíveis pelo exercício da ciência pedagógica sobre as práticas, dos saberes teóricos constituídos na tradição investigativa e das exigências postas pela sociedade com relação a propósitos formativos dos sujeitos.

Há de se convir que essas dimensões, apesar de conectadas entre si, nem sempre estão em perfeita sintonia, já que procedem de diferentes lógicas, em tempos diversos e com diferentes intencionalidades. É sabido, por exemplo, como políticas curriculares acabam atendo-se exclusivamente 
Diretrizes curriculares da pedagogia: imprecisōes teóricas...

aos saberes práticos, desconhecendo a dimensão epistemológica de um campo científico, ou de como saberes teóricos podem não se transformar, necessariamente, em saberes práticos ou mesmo em matérias de ensino. Pimenta (1999) afirma que os saberes sobre a educação e sobre a pedagogia não geram os saberes pedagógicos. Estes só se constituem a partir da prática que os confronta e os reelabora. Mas os saberes sobre a educação e sobre a pedagogia também não são gerados só com o saber da prática.

A pedagogia, integrando as três dimensões mencionadas, poderá preocupar-se com as possibilidades de construção de teorias a partir da prática, criando estratégias didáticas e investigativas que auxiliarão na composição de possíveis saberes pedagógicos, que poderão servir de apoio para a compreensão e a transformação das práticas, em ações críticas, realizadas pelos próprios docentes.

Vê-se que há muita coisa a considerar quando se trata de pensar a formação de educadores, seja na pesquisa, seja na docência, seja na legislação. Desconsiderada em sua dimensão epistemológica, que define seu campo científico e profissional, a pedagogia acaba por ser reduzida à dimensão metodológica e procedimental, o que também dificulta a compreensão e a construção da identidade profissional do pedagogo, seja ele professor ou especialista. Desprovida de conteúdos próprios e de métodos próprios de produção de saberes, a pedagogia facilmente se converte em tecnologia, em modo de fazer, em fazeres práticos. A capacidade de articular o aparato teórico-prático, de mobilizá-lo na condição presente, de organizar novos saberes a partir da prática, essas capacidades em conjunto estruturam aquilo que chamamos de saberes pedagógicos, suportes dos saberes disciplinares. Sendo assim, o curso de pedagogia constitui o único curso de graduação cuja especificidade é proceder à análise crítica e contextualizada da educação e do ensino na qualidade de práxis social, formando o profissional pedagogo, com formação teórica, científica, ética e técnica com vistas ao aprofundamento na teoria pedagógica, na pesquisa educacional e no exercício de atividades pedagógicas específicas.

Uma legislação mais conseqüente para a formação de educadores em cursos de pedagogia e cursos de formação de professores

Um documento sobre Diretrizes Curriculares Nacionais para os cursos de graduação em pedagogia deveria regulamentar a formação de pedagogos-especialistas por meio de estudos teóricos da pedagogia, pre- 
paração para investigação científica e para o exercício profissional no sistema de ensino, nas escolas e em outras instituições educacionais, incluindo as não-escolares. Em seu exercício profissional, o pedagogo deve estar habilitado a desempenhar atividades relativas a: formulação e gestão de políticas educacionais; avaliação e formulação de currículos e de políticas curriculares; organização e gestão de sistemas e de unidades escolares; planejamento, coordenação, execução e avaliação de programas e projetos educacionais para diferentes faixas etárias; formulação e gestão de experiências educacionais; coordenação pedagógica e assessoria didática a professores e alunos em situações de ensino e aprendizagem; coordenação de atividades de estágios profissionais em ambientes diversos; avaliação e desenvolvimento de práticas avaliativas no âmbito institucional e nos processos de ensino e aprendizagem em vários contextos de formação; produção e difusão de conhecimento científico e tecnológico do campo educacional; formulação e coordenação de programas e processos de formação contínua e desenvolvimento profissional de professores em ambientes escolares e não-escolares; produção e otimização de projetos destinados à educação a distância e a mídias educativas como vídeos e outras; desenvolvimento cultural e artístico para várias faixas etárias.

Em ligação direta com esse curso específico de pedagogia, os cursos destinados à formação de professores para a educação básica também devem ser oferecidos nas faculdades de educação, entendendo ser o magistério indubitavelmente uma atividade pedagógica. Entretanto, esses cursos já estão regulamentados pelas Resoluções n. 1 e 2/2002 do CNE, atendendo ao artigo 62 da Lei de Diretrizes e Bases da Educação Nacional (Lei n. 9.393/96). São dois cursos na mesma instituição, articulados entre si, porém com uma estrutura curricular distinta.

As faculdades de educação poderão oferecer outras modalidades de cursos de especialização ou aperfeiçoamento para professores das redes públicas e privadas de ensino. Devem criar um espaço institucional que assegure a presença de professores das escolas públicas em cursos e eventos formativos, possibilitando a relação teoria e prática para os professores em exercício e para os alunos da formação inicial, como forma de ajudá-los na iniciação à aprendizagem da profissão docente.

Os termos da legislação aqui proposta atribuiriam ao curso de pedagogia as seguintes características:

- A formação dos profissionais da educação para atuação na educação básica e em outras instâncias de prática educativa, far-se-

Educ. Soc., Campinas, vol. 27, n. 96 - Especial, p. 843-876, out. 2006 
Diretrizes curriculares da pedagogia: imprecisōes teóricas...

á exclusivamente em faculdades de educação, que oferecerão curso de pedagogia desdobrado em bacharelado em pedagogia e em cursos de licenciatura.

- O bacharelado em pedagogia destina-se à formação de profissionais de educação não-docentes voltados para os estudos teóricos da pedagogia e o exercício profissional no sistema de ensino, nas escolas e em outras instituições educacionais, inclusive não-escolares, conforme habilitaçōes a definir.

- Os cursos de licenciatura destinam-se à formação de professores para a educação infantil e as séries iniciais do ensino fundamental, e, em médio prazo, para toda a educação básica.

- Tanto o bacharelado em pedagogia quanto os cursos de licenciatura poderão oferecer, ao final do curso, habilitaçôes conexas, tendo em vista favorecer modalidades flexíveis de formação conforme necessidades detectadas no âmbito do funcionamento interno das escolas e de outras instituições educacionais não-escolares.

São previstas, no interior da faculdade de pedagogia, modalidades diversas de formação continuada, promovendo alternância entre a formação inicial e a formação profissional contínua, envolvendo alunos dos cursos e professores das redes de ensino. Um centro de formação continuada com essas características desenvolveria, em caráter sistemático, assistência pedagógico-didática aos professores das redes de ensino, coordenação de atividades de estágio, estrutura de apoio didático e tecnológico (vídeo, cinema, internet, uso de computadores, equipamentos de som e imagem), biblioteca e centro de documentação à disposição de professores e alunos, oficinas, exposições e feiras, publicação de periódicos de cunho pedagógico-didático.

Com esse entendimento, somente faz sentido existir uma faculdade de educação (faculdade de pedagogia) se ela tiver, também, o curso de pedagogia voltado aos estudos específicos da ciência pedagógica, para, entre outras habilitações, formar pedagogos-especialistas para a escola. E, é claro, que forme também professores para a educação infantil e o ensino fundamental e para toda a educação básica. $\mathrm{O}$ curso de pedagogia oferecerá, portanto, três habilitações: bacharelado em pedagogia, licenciatura em educação infantil e licenciatura em anos iniciais do ensino fundamental. E, quando a formação de professores for levada ainda mais a sério, que na faculdade de pedagogia sejam oferecidas todas as licenciaturas da educação básica. 
Este posicionamento torna explícita a integração das três dimensões da pedagogia. Sua epistemologia, fundada na tradição teórica e nos saberes da prática, funde-se com as condiçōes históricas atuais, para fornecer os elementos de elaboração da legislação, particularmente das Diretrizes Curriculares Nacionais para os cursos de pedagogia. É esse caminho que poderia abrir espaços políticos e institucionais para a retirada do pedagogo do limbo profissional e identitário em que se encontra e de sua falsa e inconsistente identificação como professor. Com efeito, o esfacelamento dos estudos no âmbito da ciência pedagógica, com a conseqüente subsunção do especialista no docente, e a improcedente identificação dos estudos pedagógicos com uma licenciatura talvez sejam dois dos mais expressivos equívocos teóricos e operacionais da legislação, herdados dos movimentos de reformulação dos cursos de formação do educador, no que se refere à formação do pedagogo.

O posicionamento que nos move é a crença no poder social e político da escola, tendo como base o direito de todos, em condições iguais de oportunidades de acesso aos bens culturais, ao desenvolvimento das capacidades individuais e sociais, à formação da cidadania, à conquista da dignidade humana e da liberdade intelectual e política, enfim, das justas liberdades. Este é um trabalho para professores e para pedagogos-especialistas, e é nessa direção que os cursos de formação precisam caminhar.

Recebido e aprovado em agosto de 2006.

\section{Notas}

1. É inteiramente oportuna e lúcida a declaração de voto do conselheiro Francisco Cordão, contrária à redação do artigo 14 da Resolução do $\mathrm{CNE}$ onde se lê: "O preâmbulo do Projeto de Resolução anexo ao Parecer CNE/CP n. 5/2005 claramente define que este regulamenta o art. 62 da LDB, isto é, formação de docentes em cursos de licenciatura para atuar na Educação Básica. O referido Parecer não disciplina o art. 64 da LDB, que trata da formação de outros profissionais de educação que não os professores. (...) Julgo muito mais adequada, para contemplar as preocupaçōes, em relação ao art. 64 da LDB, a supressão pura e simples do referido art. 14 do Projeto de Resolução anexo ao Parecer CNE/CP n. 5/2005. A emenda retificativa proposta pela Comissão Bicameral de Formação de Professores transforma o curso de pedagogia em um curso genérico e desfigurado, sem condiçóes de contribuir efetivamente tanto para a valorização dos professores e da sua formação inicial quanto para o aprimoramento da Educação Básica no Brasil”.

2. Cf. capítulo III da obra Pedagogia e pedagogos, para quê?, de José Carlos Libâneo, Cortez, 1998 (2005).

3. Registre-se, para ilustração, que uma Comissão de Especialistas de ensino de pedagogia, em 1995, traduzindo as idéias da ANFOPE, assim define o pedagogo: "Profissional habilitado a 
Diretrizes curriculares da pedagogia: imprecisões teóricas...

atuar no ensino, na organização e na gestão de sistemas, unidades e projetos educacionais e na produção e difusão do conhecimento, em diversas áreas da educação, tendo a docência como base obrigatória de sua formação e identidade profissionais".

4. Por exemplo, o curso de pedagogia, da Faculdade de Educação da Universidade Federal de Goiás, conforme Resolução CCEP n. 207/1984, estabelece em seu artigo 1: "O curso de graduação em pedagogia, que conferirá o grau de Licenciado, destina-se à formação de professores para o ensino das matérias pedagógicas no $2^{\circ}$ grau e para o exercício do magistério nas séries iniciais do ensino de $1^{\circ}$ grau".

5. Não é demais reiterar que considero inadequada a expressão "pedagogo" para designar o professor, e apenas o professor, institucionalizando equivocadamente a designação de pedagogo ao profissional formado no curso definido pela Resolução.

6. Cumpre registrar que, desde o início dos debates promovidos pelo MEC e por associaçôes independentes de educadores, por volta de 1980, sobre a reformulação dos cursos de pedagogia, os documentos dos educadores, a par de entender a natureza do curso como formação do professor, também o analisam e discutem como "espaço de permanente reflexão crítica", tendo uma função teórica "de transmissão, crítica e construção de conhecimento sobre a ciência da educação", a importância da pedagogia para as demais licenciaturas e a pertinência da discussão sobre as habilitações (II Encontro Nacional, CONARCFE, 1986; IV Encontro, Documento Final, CONARCFE, 1989). Entretanto, o cunho pedagógico-científico das discussões foi se perdendo a partir dos anos de 1990. Com efeito, mesmo reconhecendo o papel destacado das associações de educadores, especialmente após a criação da Comissão Nacional pela Reformulação dos Cursos de Formação do Educador, na discussão política da formação expressa em temas como a defesa da autonomia universitária, a gratuidade do ensino, a democratização dos órgãos decisórios do MEC, a democratização das formas de gestão, a ampliação de recursos financeiros para a educação, não se pode dizer que tiveram êxito com relação à consolidação da base comum nacional, da consolidação legal das recomendações pedagógicas e curriculares, da efetiva institucionalização das mudanças pretendidas no sistema de ensino sobre uma política unitária de formação de educadores e da melhoria qualitativa da formação nos cursos de pedagogia.

7. Movo-me nesta argumentação com a apropriação livre de algumas idéias de Paro, 1986.

8. Suchodolski escreve que "a pedagogia é a ciência que investiga a realidade educacional mutável, o que significa que o objeto de suas investigações é historicamente mutável” (1977, p. 12).

9. As idéias expressas a seguir foram baseadas em texto ainda não publicado, no qual são apresentadas essas três abordagens da pedagogia (Franco, Libâneo \& Pimenta, 2006).

\section{Referências bibliográficas}

BRASIL. Ministério da Educação. Conselho Nacional de Educação. Projeto de Resolução do CNE. Brasília, DF, 2005.

BRASIL. Ministério da Educação. Secretaria de Educação Superior. Comissão de Especialistas do Curso de Pedagogia. Proposta de diretrizes curriculares para o curso de pedagogia. Brasília, DF: MEC/SESU, 1999.

BRASIL. Ministério da Educação. Universidade Federal de Goiás. Resolução CCEP n.207 e exposição de motivos. 1984. 
ENCONTRO Nacional da Associação Nacional pela Formação dos Profissionais da Educação (ANFOPE), 6., 1992, Belo Horizonte. Documento final. Belo Horizonte: ANFOPE, 1992.

ENCONTRO Nacional da Comissão pela Reformulação dos Cursos de Formação do Educador, 2., 1986. Documento final. Goiânia: CONARCFE, 1986.

ENCONTRO Nacional da Comissão pela Reformulação dos Cursos de Formação do Educador., 5. 1990, Belo Horizonte. Documento final. Belo Horizonte: CONARCFE, 1990.

ENCONTRO Nacional de Reformulação dos Cursos de Preparação de Recursos Humanos para a Educação, 1983, Belo Horizonte. Documento final. Belo Horizonte, 1983.

DURKHEIM, É. Educação e sociologia. São Paulo: Melhoramentos, 1967.

FORUM DE DIRETORES DAS FACULDADES DE EDUCAÇÃO DAS UNIVERSIDADES PUBLICAS BRASILEIRAS (FORUMDIR). Consideraçôes sobre a Proposta de Diretrizes do CNE. Maceió, 2005.

FRANCO, M.A.S. Pedagogia como ciência da educação. Campinas: Papirus, 2003a.

FRANCO, M.A.S. A pedagogia para além dos confrontos. In: Fórum de Educação: pedagogo, que profissional é esse? 2003, Belo Horizonte. Anais... Belo Horizonte: FAE/CBH/UemG, 2003b. v. 1, p. 39-68.

FRANCO, M.A.S. Saberes pedagógicos e prática docente. In: ENCONTRO Nacional de Didática e Prática de Ensino (ENDIPE). Anais... : educação formal e não-formal, processos formativos e saberes pedagógicos. Recife: Bagaço, 2006. v. 1, p. 27-50.

FRANCO, M.A.S.; LIBÂNEO, J.C.; PIMENTA, S.G. Elementos teóricos e práticos para a formulação de diretrizes curriculares para cursos de pedagogia. São Paulo, 2006. (Texto digitado)

HERBART, J.F. Pedagogia geral. Lisboa: Fundação Calouste Gulbenkian, 2003.

LIBÂNEO, J.C. Ainda as perguntas: o que é pedagogia, quem é o pedagogo, o que deve ser o curso de pedagogia. In: PimenTA, S.G. (Org.). Pedagogia e pedagogos: caminhos e perspectivas. São Paulo: Cortez, 2002.

Educ. Soc., Campinas, vol. 27, n. 96 - Especial, p. 843-876, out. 2006 
Diretrizes curriculares da pedagogia: imprecisões teóricas...

LIBÂNEO, J.C. O debate sobre o estudo científico da educação: ciência pedagógica ou ciências da educação? Revista Espaço Pedagógico, Passo Fundo, v. 10, n. 2, jul./dez. 2003.

LIBÂNEO, J.C. Pedagogia e pedagogos, para quê? São Paulo: Cortez, 2005a.

LIBÂNEO, J.C. Organização e gestão da escola. Goiânia: Alternativa, 2005b.

LIBÂNEO, J.C.; OLIVEIRA, J.F.; TOSCHI, M.S. Educação escolar: políticas, estrutura e organização. São Paulo: Cortez, 2005.

LIBÂNEO, J.C.; PIMENTA, S.G. Formação dos profissionais da educação: visão crítica e perspectivas de mudança. Educação \& Sociedade, Campinas, v. 20, n. 68, p. 239-77, 1999.

MIALARET, G. Pédagogie générale. Paris: Presses Universitaires de France, 1991.

PARO, V.H. Administração escolar: introdução crítica. 9. ed. São Paulo: Cortez; Campinas: Autores Associados, 1986.

PIMENTA, S.G. (Coord.). Pedagogia, ciência da educação? São Paulo: Cortez, 1996.

PIMENTA, S.G. Para uma re-significação da didática: ciências da educação, pedagogia e didática (uma revisão conceitual e uma síntese provisória). In: PimenTa, S.G. (Org). Didática e formação de professores: percursos e perspectivas no Brasil e em Portugal. São Paulo: Cortez, 1997. p. 19-76.

PIMENTA, S.G. Formação de professores: saberes da docência e identidade do professor. In: PIMENTA, S.G. (Org). Saberes pedagógicos e atividade docente. São Paulo: Cortez, 1999.

QUINTANAS CABANAS, J.M. Teoria de la educación: concepción antinómica de la educación. Madri: Dykinson, 1995.

RASIA, J.M. Pedagogia e educação ou de como falar sobre o óbvio. Cadernos CEDES, Campinas, n. 2, p. 21-22, 1980.

SCHMIED-KOWARZIK, W. Pedagogia dialética. São Paulo: Brasiliense, 1983.

SUCHODOLSKI, B. La educación humana del hombre. Barcelona: Laia, 1977. 